\title{
Öğretmen Adaylarının Facebook Kullanma Gerekçeleri: Siirt İli Örneği ${ }^{*}$
}

Mehmet RAMAZANOĞLU, Siirt Üniversitesi, Ĕ̆gitim Fakültesi Bilgisayar ve Öğretim

Teknolojileri Eğitimi Bölümü, Dr. Öğr. Üyesi, memedmustafa@gmail.com, ORCID: 0000-0001-68600895

Sungur GÜREL, Siirt Üniversitesi, Eğitim Fakültesi Bilgisayar ve Öğretim Teknolojileri Eğitimi Bölümü, Dr. Öğr. Üyesi, s.gurel@siirt.edu.tr, ORCID: 0000-0003-3425-858X

$\ddot{O} Z$

En çok kullanılan sosyal ăg sitesi olan Facebook, eğitsel amaçlarla da kullanılabilir. Facebook'u eğitsel ortam tasarımında daha etkin kullanabilmek için bireylerin hangi gerekçelerle Facebook'a bă̆landığıııı ve bu gerekçelerin çeşitli özelliklere göre değişip değişmediğinin belirlenmesi gereklidir. Ancak alan yazında bu konuda kabul gören bir anlayıs bulunmamaktadır. Bu çalışmanın amacı öğretmen adaylarının Facebook'a bağlanma gerekçelerini belirlemek ve çeşitli değişkenlere göre incelemektir. Nicel verilerin analizine dayanan bir betimsel tarama modeli kullanılarak yürütülen bu çalışmada, 2018-2019 Siirt Üniversitesi Ĕ̆itim Fakültesi öğrencilerinden uygun örnekleme ile 525'ine ulaşılmıştır. Çalışmada öğretmen adaylarının en çok bilgi arama, sonrasında iletişimi sürdürme ve en az iletişimi başlatma amaçlarıyla Facebook'a bağlandıkları bulgulanmıştır. Erkek öğretmen adaylarının kadın öğretmen adaylarına göre daha çok iletişimi başlatma ve iletişimi sürdürme gerekçeleriyle Facebook'a bağlandiğı tespit edilmiştir. Ancak, Facebook'a bağlanma gerekçelerinin kayıtlı olunan bölüme göre değişmediği tespit edilmiştir. Son olarak, Facebook'a bă̆lanma gerekçeleri arasinda orta ve yüksek düzeyde pozitif yönde ilişkiler tespit edilmiştir. Bu çalışma bulguları ışı̆̆ında Facebook'un eğitsel ortam tasarımında kullanıldı̆̆ı durumlarda Facebook üzerinden etkileşimi sadece aynı sınıftaki öğrenciler ile sınırlı tutmanın, Facebook üzerinden bilgi paylaşımı yapmanın etkili olacă̆ı ön görülmektedir. Benzer çalışmalar farklı sosyal ă̆g sitelerini de merkeze alarak, farklı bölgelerden üniversitelerde ve farklı bölümlerden öğrencilerle tekrarlanmalıdır. Ayrıca Facebook'a ya da herhangi bir sosyal ă̆ sitesine bağlanma gerekçelerinin sosyal sermayeyle, ders başarısıyla ve akademik özyeterlik gibi diğer özelliklerle ilişkisin de incelenmesi sosyal ăg sitelerini eğitsel amaçlarla daha aktif kullanabilmenin yolunu açacaktır.

\footnotetext{
* Bu makalenin bir k1smı 19-22 HAZİRAN 2019'da Ankara Üniversitesi'nde düzenlenen VIth. International Eurasian Educational Research Congress'de sözlü bildiri olarak sunulmuştur.
} 
Anahtar : $\quad$ Facebook, Sosyal A $\quad$ ğğ Ögretmen Adayları

Kelimeler

\section{The Reasons of Teacher Candidates to Use Facebook: Example of Siirt}

\section{ABSTRACT}

Facebook, which is the most commonly used social networking site can also be used for educational purposes. In order to use Facebook more effectively in educational environment design, it is necessary to determine the reasons why individuals are connected to Facebook and whether these reasons change according to various characteristics. However, there is not any accepted agreement regarding this field in the literature. The aim of this study is to determine the reasons why teacher candidates connect to Facebook and analyze these reasons in terms of various variables. In this study which was conducted using a descriptive screening model via the analysis of quantitative data that are obtained from 525 students, who are enrolled at Siirt University Faculty of Education during 2018-2019 academic year, were reached through convenience sampling method. We found that teacher candidates connect to Facebook most frequently for the purposes of searching for information, followed by maintaining relationship and starting relationship the least. Compared to female teacher candidates, male teacher candidates connect to Facebook more frequently with initiating a relationship and maintaining a relationship purpose. On the other hand, reasons for connecting to Facebook did not change with respect to the registered program. Finally, positive relations at medium and high levels were observed among the reasons for connecting to Facebook. In the light of the findings of this study, it is suggested that limiting the interaction through Facebook only to the students in the same class and sharing information via Facebook will be effective in situations where Facebook is used in the design of educational environments. Similar studies should be repeated with students from different programs and from universities that are in different regions by taking different social networking sites into the centre as well. In addition, analyzing the reasons for connecting to Facebook or any other social networking site with respect to other student characteristics such as social capital, school success and academic self-efficacy will lead to more active use of social networking sites for educational purposes.

Keywords : Facebook, Social Network, Teacher Candidates 


\section{GíRIŞ}

Teknolojilerindeki yaşanan gelişmelerin hızlı ilerleyişi yaşantımızı birçok yönden yoğun bir şekilde etkilemektedir. Bu teknolojik gelişmelerin bir parçası da internet teknolojisidir. Gelişen internet teknolojisi ile birlikte sosyal ağ sitelerinin yeni bir iletişim aracı olarak görüldüğü söylenebilir. Sosyal ağ siteleri sayesinde bireyler arasındaki iletişim ve etkileşim farklı bir mecraya taşınmıştır. Kullanıcılar sosyal ağlarda kişisel ifadeler kullanma, kendilerini tanıtma, iletişim kurma ve sürdürme, içerik paylaşma (ses, çeşitli fotoğraf, videolar, vb.) ve yeni arkadaşlar edinme olanağı sağlamaktadır (Kim, Jeong ve Lee, 2010; Wang, Moon, Kwon, Evans ve Stefanone, 2010). Günümüzde en fazla kullanıcısı olan sosyal ağ sitesi Facebook'dur (Lua, 2019). Facebook 2004 yılından bu yana, kullanıcıların birbiriyle iletişim kurarak, bu iletişimi sürdürmelerini kolaylaştırarak ve yenileyerek sosyal medya ortamlarındaki benzer sosyal ağ sitelerinden daha üstün olduğu görülmektedir (Korkmaz, 2012). Facebook; kullanıcıların, kişiye özel oluşturdukları profil ile birbirleriyle iletişim kurma, guruplar oluşturma, guruplara katılma, bilgi arama ve kaynak paylaşmayı sağlayan bir ağ ortamıdır (Gonzales ve Vodicka, 2010). We are social ve Hootsuit şirketleri tarafından yayınlanan 2020 sosyal medya istatistiklerini içeren "Digital 2020 (Turkey)" raporuna göre, 83.88 milyon nüfusa sahip olan ülkemizde 62.7 (74\%) milyon kişi internet kullanmaktadır. Aynı rapora göre, Türkiye'de 37 milyon Facebook hesabı bulunmaktadır. Bu sayı ile Türkiye, Facebook kullanıcı sayısı açısından ülkeler sıralamasında 10. sırada yerini almıştır. Ayrıca Türkiye'deki üniversite öğrencileri arasında en çok tercih edilen sosyal ağ sitesi de Facebook'dur (Diker ve Uçar, 2016; Günindi Ersöz, 2016; Solmaz, Tekin, Herzem ve Demir, 2013). Alanyazın incelendiğinde üniversite öğrencilerinin sosyal ă̆ kullanımlarına ilişkin yapılan araştırmaların (Aktürk, Emlek ve Çelik, 2017; Çam, 2012; Dilek ve Uçar, 2016; Günindi ve Ersöz, 2016; Filiz, Erol, Dönmez ve Kurt, 2014; Pempek, Yermolayeva ve Calvert, 2009; Ramazanoğlu ve Çetin, 2019; Serdar, Harmandar Demirel ve Demirel, 2018; Sheldon, 2008; Solmaz, Tekin, Herzem ve Demir, 2013) sayısının son yıllarda arttığ1 söylenebilir. Söz konusu çalışmalarda ana temalar; sosyal ağ kullanma gerekçeleri, sosyal ağ bağımlılığı ve sosyal ağ kullanmanın oluşturduğu olumlu ve olumsuz sonuçlar olarak özetlenebilir. Bu çalışmada ise Türk üniversite öğrencileri arasında en çok kullanılan sosyal ağ olan Facebook'a bağlanma gerekçeleri merkeze alınmıştır.

Üniversite öğrencilerinin Facebook'a bağlanma gerekçeleri incelenirken karşımıza çıkan yapılar arasında sosyal etkileşim-iletişim, tanıma-tanınma, eğitim (Filiz, Erol, Dönmez ve Kurt, 2014; Ramazanoğlu ve Çetin, 2019), sosyal ilişkiler, çalışmalara ilişkin kullanım, gündelik etkinlikler (Çam, 2012; Serdar, Harmandar Demirel ve Demirel, 2018), başlatma, sürdürme, bilgi arama (Aktürk, Emlek ve Çelik, 2017) araştırma, işbirliği, iletişim başlatma ve kurma, iletişim sürdürme (Diker ve Uçar, 2016) bulunmaktadır. Sosyal ilişkiler boyutunun hem iletişimi başlatma hem de iletişimi sürdürmeyi içerdiğini göz önüne alırsak, bu çalışmalarda ele alınan yapıların neredeyse tamamını iletişimi başlatma, iletişimi sürdürme ve 
bilgi arama şemsiyesi altında toplamak mümkündür. Bu çalışmada bu üç Facebook'a bağlanma gerekçesi ele alınmıştır. Hew (2011), Öğrencilerin Facebook'u en çok tanıdıkları kişiler ile iletişim kurmak ve kişisel paylaşım için kullandıklarını, en az ise eğitim amaçlı kullandıklarını belirtmiştir. Bolat (2018). Öğretmen adaylarının Facebook'u çoğunlukla arkadaşlarıyla iletişim kurmak için kullandıklarını ifade etmiştir.

Facebook'a bağlanma gerekçelerinin sıralanması incelendiğinde farklı çalışmalarda farklı sıralamalar karşımıza çıkmaktadır. Aktürk ve ark. (2017) en fazla kullanılan bağlanma gerekçesinin iletişimi başlatma, sonra iletişimi sürdürme ve en az da bilgi arama olduğunu raporlamıştır. Ancak, Diker ve Uçar (2016), en çok bilgi arama, sonrasında iletişimi sürdürme ve en az da iletişimi başlatma amacıyla Facebook'a bağlanıldığını raporlamıştır. Ayrıca Solmaz, Tekin, Herzem ve Demir de (2013) iletişimi sürdürme gerekçesinin iletişimi başlatma gerekçesinden daha fazla kullanıldığını bulgulamıştır. Pempek, Yermolayeva ve Calvert'de (2009) Facebook'un en çok daha önceden tanınan insanlarla sosyal etkileşimin sürdürülmesi için kullanıldığını belirtmiştir. Öte yandan, bilgi arama gerekçesinin hem iletişimi başlatma hem de iletişimi sürdürme boyutlarını kapsayan sosyal ilişkiler gerekçesinden daha ön plana çıktığ1 çalışmalar (Filiz, Erol, Dönmez ve Kurt, 2014; Serdar, Harmandar Demirel ve Demirel, 2018) olduğu gibi bu iki yapının yer değiştirdiği çalışmalar da (Çam, 2012; Ramazanoğlu ve Çetin, 2019) mevcuttur. Facebook'a tanıma ve tanınma amacı ile bağlanılmasının başlatma boyutu ile doğrudan ilişkili olduğunu düşünürsek, Filiz, Erol, Dönmez ve Kurt (2014) ve Ramazanoğlu ve Çetin (2019) en az iletişimi başlatma amacıyla Facebook'a bağlanıldığını bulgulamıştır.

Facebook'a bağlanma gerekçelerinin cinsiyete göre farklılaşıp farklılaşmadı̆̆ını inceleyen çalışmalara bakıldığında ise iletişimi başlatma gerekçesinin erkekler tarafından daha fazla kullanıldığı (Aktürk, Emlek ve Çelik, 2017; Filiz, Erol, Dönmez ve Kurt, 2014; Ramazanoğlu ve Çetin, 2019; Sheldon, 2008) bulgulanmıştır. Ayrıca erkekler, Çam (2012) ve Serdar, Harmandar Demirel ve Demirel'e (2018) göre sosyal ilişkiler gerekçesiyle Facebook'a daha çok bağlanmaktadır. İletişimi sürdürme gerekçesi Aktürk, Emlek ve Çelik'e (2017) göre erkekler tarafından daha çok, Diker ve Uçar'a (2017) ve Sheldon'a (2008) göre ise kadınlar tarafından daha çok kullanılmaktadır. Son olarak Diker ve Uçar (2017) ve Ramazanoğlu ve Çetin (2019), bilgi arama gerekçesinin kadınlar tarafından daha fazla kullanıldığını bulgulamıştır. Hargittai ve Hsieh (2010) araştırmalarında kadınların sosyal ağ sitelerini ilişkiyi sürdürme amaçlı kullanırken, erkeklerin ise sosyal ağ sitelerini tanışma amaçlı kullandıklarını bulmuşlardır.

Facebook'a bağlanma gerekçelerinin bölüme göre farklılaşıp farklılaşmadığını ele alan çalışmalardan Siirt Üniversitesi Eğitim Fakültesi'nde bulunan bölümler incelendiğinde Ramazanoğlu ve Çetin (2019) bölüme dayalı bir farklılaşma rapor etmemiştir ancak Çam (2012), BÖTE öğretmen adaylarının hem İlköğretim Matematik hem de Türkçe öğretmen adaylarına kıyasla daha çok sosyal ilişkiler ve bilgi arama gerekçeleriyle Facebook'a bağlandığını bulgulamıştır. Benzer farklılık aynı alanlarda Sınıf ve Türkçe öğretmen adayları 
arasında ve Fen Bilgisi ve Türkçe öğretmen adayları arasında da bulgulamıştır. Ayrıca yine aynı çalışma sonuçlarına göre BÖTE öğretmen adayları, Facebook'a bilgi arama gerekçesiyle Sosyal Bilgiler öğretmen adaylarından daha fazla bağlanmaktadır.

Alan yazında yer alan çalışmaların sonuçları incelendiğinde Facebook'a bağlanma gerekçeleri ve bu gerekçelerin nelere göre farklılık gösterdiği üzerinde genel kabul gören bir anlayış bulunmamaktadır. Öğrencilerin Facebook'u; tanışmak, birilerini bulmak, arkadaşlarıyla iletişim kurmak, sınıf arkadaşlarını veya yakın çevredeki bireyler hakkında bilgi edinmek için kullandıkları söylenilebilir. Ancak hangi gerekçenin daha ön plana çıktığı ve bu durumun hangi bölüm öğrencileri için ve hangi cinsiyetteki öğrenciler için geçerli olduğu açık değildir. $\mathrm{Bu}$ çalışmanın amacı öğretmen adaylarının tüm dünyayı birbirine bağlayan ve kendini ifade ederek farklı bireylerle iletişime geçmeyi sağlayın Facebook'a bağlanma gerekçelerini belirlemek ve çeşitli değişkenlere göre incelemektir. Öğretmen adaylarının Facebook'a bağlanma gerekçelerinin belirlenmesi ile söz konusu gerekçeler de göz önüne alınarak tasarlanacak eğitim-öğretim ortamları, daha etkili olabilir.

\section{Araştırmanın Amacı}

$\mathrm{Bu}$ araştırmanın amacı, öğretmen adayların Facebook'a bağlanma gerekçelerinin belirlenmesidir. Bu amaç doğrultusunda araştırmada şu sorulara yanıt aranmıştır.

口 Öğretmen adayları daha çok hangi gerekçelerle Facebook'a bağlanmaktadır?

口 Öğretmen adaylarının Facebook'a bağlanma gerekçeleri; cinsiyet ve bölüm bağımsız değişkenlere göre anlamlı bir farklılık göstermekte midir?

口 Öğretmen adaylarının Facebook'a bağlanma gerekçeleri arasındaki ilişkinin yönü ve miktarı nedir?

\section{YÖNTEM}

\section{Araştırma modeli}

Öğretmen adaylarının Facebook'a bağlanma gerekçelerini belirlemeyi amaçlayan bu araştırma, nicel verilerin analizine dayanan bir betimsel tarama modeli kullanılarak yürütülmüştür. Betimsel tarama modeli, mevcut durumun özelliklerini değiştirmeden betimleyen bir araştırma modelidir (Kaptan, 1998). Betimsel tarama modeli var olan durumun olduğu gibi betimlemeye ve incelemeye çalışan bir modeldir (Karasar, 2015).

\section{Örneklem}

Araştırmanın evrenini 2018-2019 eğitim-öğretim yılında Siirt Üniversitesi Eğitim Fakültesinde öğrenim gören toplam 1871 öğretmen adayı oluşturmaktadır. Araştırmada uygun örnekleme yöntemi kullanılmıştır. Uygun örnekleme yöntemi, kolay ulaşılabilir kişilerin seçilmesiyle oluşturulan örnekleme yöntemidir (Fraenkel, Wallen ve Hyun, 2012). Evrene genelleme 
kaygısı taşımadan sadece öğretmen adaylarının Facebook bağlanma stratejileri üzerine bir alg1 elde edilmeye çalışılmıştır. Çalışmaya, veri toplanan günlerde dersi olan öğretmen adayları arasından veri toplama aracını doldurmak için gönüllü olan toplam 525 öğretmen adayı katılmıştır. Araştırmaya katılan öğretmen adaylarına ilişkin betimsel özellikler Tablo 1'de sunulmuştur.

Tablo 1. Araştırmaya katılan öğretmen adaylarının betimsel özellikleri

\begin{tabular}{lll}
\hline & Frekans & Yüzde (\%) \\
\hline $\begin{array}{l}\text { Cinsiyet } \\
\text { Kadın }\end{array}$ & 326 & 62,1 \\
Erkek & 199 & 37,9 \\
Bölüm & & \\
Sosyal Bilgiler Öğretmenliği & 160 & 30,5 \\
Sınıf Öğretmenliği & 103 & 19,6 \\
Fen Bilgisi Öğretmenliği & 72 & 13,7 \\
Türkçe Öğretmenliği & 68 & 13,0 \\
İlköğretim Matematik Öğretmenliği & 61 & 11,6 \\
Bilgisayar ve Öğretim Teknolojileri Ĕgitimi & 61 & 11,6 \\
\hline
\end{tabular}

Not: $n=525$

Tablo 1 incelendiğinde katılımcıların 326's1 (\%62,1) kadın, 199’u (\%37,9) erkektir. Bölümlere göre ise; 160’1 (\%30,5) Sosyal Bilgiler Öğretmenliği (SBÖ), 103’u (\%19,6) Sınıf Öğretmenliği (SÖ), 72'si (\%13,7) Fen Bilgisi Öğretmenliği (FBÖ), 68'i (\%13,0) Türkçe Öğretmenliği (TÖ), 61'i $(\% 11,6)$ İlköğretim Matematik Öğretmenliği (IMMÖ) ve 61’i $(\% 11,6)$ Bilgisayar ve Öğretim Teknolojileri Eğitimi (BÖTE) öğretmen adaylarıdır.

\section{Veri Toplama Arac1}

Çalışmada nicel veri toplama aracı Ellison, Steinfield ve Lampe (2011) tarafından geliştirilen Aktürk, Çelik, Şahin ve Deniz (2014) tarafından Türkçeye uyarlanan "Facebook Bağlanma Stratejileri Ölçeği (FBSÖ)” kullanılmıştır. FBSÖ, başlatma (5 madde), sürdürme (4 madde) ve bilgi arama ( 3 madde) boyutlarından oluşmaktadır. Ölçeğin ilk 8 maddesi için "hiç uygun değil, uygun değil, kararsızım, uygun, oldukça uygun" seçenekleri, son 4 maddesi ise “kesinlikle katılmıyorum, katılmıyorum, kararsızım, katılıyorum, kesinlikle katılıyorum" seçenekleri yer almaktadır. FBÖS ile sıralandırma seviyesinde veri toplanmıştır. Ayrıca bu çalışma için güvenirlik kanıtı olarak elde edilen Cronbach Alpha iç tutarlık katsayıları, başlatma boyutu için .809 , sürdürme boyutu için .806 ve bilgi arama boyutu için .811 olarak hesaplanmıştır. Bu sonuçlar ışığında her bir boyut için elde edilen puanının güvenilir olduğu söylenilebilir. 


\section{Verilerin Analizi}

Birinci araştırma sorusunu cevaplandırmak için FBSÖ ile toplanan verinin eşit aralıklı olduğu varsayılıp her bir boyut için toplam boyut puanları oluşturulmuştur. Oluşturulan toplam boyut puanların karşılaştırılabilir olması için her bir toplam boyut puanı en az 0, en fazla 100 olacak şekilde ölçeklendirilmiştir. Elde edilen ölçeklendirilmiş toplam boyut puanları ortalamaları hesaplanmış ve gruplar içi ANOVA ile karşılaştırılmıştır. Gruplar içi ANOVA gerçekleştirilirken normal dağılım sayıltısı, büyük örneklem üzerinde çalışıldığı için merkezi limit teoremine (Feller, 1971) dayanılarak göz ardı edilmiştir. Eş-varyanslılık sayıltısının sağlanması için serbestlik derecesinde Satterthwaite düzetlemesi (Satterthwaite, 1946) yapılmıştır. Öğretmen adaylarının formları bireysel olarak doldurdukları göz önüne alınarak bağımsızlık sayıltısının reddedilemeyeceği sonucuna ulaşılmıştır. İkili karşılaştırmalar yapılırken aile boyu I. Tip hata miktarını .05 ile sınırlandırmak için Bonferroni düzeltmesi (Miller, 1981) yapılarak anlamlılık düzeyi .05/3=.0133 olarak değerlendirilmiştir. Boyut seviyeleri arasındaki farklılığı daha iyi yorumlayabilmek için Cohen's D etki büyüklüğü istatistiği hesaplanmıştır. Cohen (1988) tarafından sunulan I.20l'lik Cohen's D küçük, I.50|'lik Cohen's d orta ve son olarak I.80|'lik Cohen's D büyük etki yorumlamaları yapılmıştır. Birinci araştırma sorusunun cevaplandırılmasında R 3.6.1 (R Core Team, 2019) istatistiksel analiz programından ve aynı programda tanımlı "lmerTest" versiyon 3.1-0 (Kuznetsova, Brockhoff ve Christensen; 2017) kütüphanesi kullanılmıştır.

İkinci ve üçüncü araştırma sorularının cevaplandırılmasında yapısal eşitlik modelleri teorik çerçevesinden faydalanılmıştır. Bu teorik çerçevesinin seçilmesinin iki önemli gerekçesi vardır. Hem FBSÖ'nün yapı geçerliği test edilebilecektir, hem de FBSÖ’den elde edilen boyut seviyeleri ortalamaları karşılaştırmaları ölçme hatalarından etkilenmeyecektir. Birinci gerekçe adına oluşturulan ölçme modeli, doğrulayıcı faktör analizi test edilmiştir. Bu modelde FBSÖ’ye verilen cevaplar gösterge değişkenleri, daha önce bahsedilen üç boyut ise içsel değişken olarak yer almaktadır. Boyut puanları arasındaki kovaryansların serbestçe hesaplanmasına izin verilmiştir. Ayrıca FBSÖ ile sıralandırma seviyesinde veri toplandığı göz önüne alınarak doğrulayıcı faktör analizinde örneklem büyüklügünün 200'ün üzerinde olduğu durumlarda bu türde veriler için en uygun seçenek olan “Diagonally Weighted Least Squares Mean and Variance Adjusted" (WLSMV) kestiricisi, (Bandalos, 2014; Flora \& Curran, 2004; Li, 2016; Sass, Schmitt, \& Marsh, 2014) kullanılmıştır. WLSMV kestiricisinin benzer analizlerde sıklıkla kullanılan "Maximum Likelihood" (ML) kestiricisine kıyasla en önemli avantajı; ML kestiricisinin gerektirdiği gösterge değişkenlerin normal dağılıma sahip bir evrenden elde edilmiş olmasını gerektirmemesidir. WLSMV ile yapılan kestirimlerde gösterge değişkenlerin herhangi bir dağılıma sahip olması gerekmez ancak gösterge değişkenlerin altında yatan gerekçeleri temsil eden gizil değişkenlerin (bu çalışma için Facebook'a bağlanma gerekçeleri) normal dağılım göstermesi gereklidir. Bu çalışmada bireylerin Facebook'a bağlanma gerekçelerinin normal dağılım gösterdiği varsayılmıştır. Model-veri uyum 
istatistikleri ile FBSÖ puanları için yapı geçerliği kanıtı oluşturulmuştur. İkinci gerekçe adına ise yapisal regresyon modeli oluşturulmuştur. Bu modelde birinci gerekçede yer alan önceki ölçme modeli aynen yer almaktadır. Ölçme modeline ek olarak, cinsiyet ve kayıtlı olunan bölümü ise dışsal değişkenler yer almaktadır. Yine WLSMV kestiricisi kullanılmıştır. Oluşturulan bu yapısal regresyon modeli ile yine model-veri uyumu kontrol edildikten sonra dışsal değişkenlere ait regresyon katsayıları ortalama farkları olarak yorumlanmıştır. Analizlerin tamamı MPlus versiyon 7.0 (Muthén \& Muthén, 2012) kullanılarak gerçekleştirilmiştir.

\section{Model-Veri Uyumu}

Model-veri uyumu incelenirken (i) model $\chi^{2}$, serbestlik derecesi ve $p$ değeri, (ii) CFI, (iii) SRMR ve (iv) RMSEA ve RMSEA için\%90 güven aralı̆̆ı göz önüne alınmıştır. Bu model test istatistiği ve üç uygunluk indeksinden oluşan küme, uyum değerlendirmesinde sunulması gereken asgari istatistikleri içermektedir (Kline, 2016). Model $\chi^{2}$, serbestlik derecesi ve $p$ değgri ile tam uyum test edilir. $p$ değerinin $.05^{\prime}$ den küçük olması, $\alpha=.05$ seviyesinde modelin-veri uyumunun tam uyumdan anlamlı derecede farklı olduğuna işaret eder (Kline, 2016). Hu ve Bentler (1999), yakın uyum istatistikleri olan $C F I$ ve $S R M R$ indekslerinin beraber değerlendirilmesi gerektiğini, kabul edilebilir uyum kararına ulaşılabilmesi için ise $C F I \geq .95$ ve $S R M R \leq .080$ olması gerektiğini belirtmiştir. Yine yakın uyum istatistiği olan $R M S E A$ iki farklı açıdan değerlendirilmektedir. RMSEA değerinin .06'ya yakın olması iyi uyuma işaret eder (Hu \& Bentler, 1999). Ayrıca RMSEA için \%90 güven arahı̆̆ıın alt sınırının .05'den küçük olması yakın uyum hipotezinin sağlandığı, üst sınırının .10' dan büyük olması ise kötü uyum hipotezinin sağlandığını ifade eder. RMESA için \%90 güven aralığının alt sınırının .05'den büyük, üst sınırınınsa $.10^{\prime}$ dan küçük olması ise yakın olmayan uyum hipotezinin sağlandığının göstergesidir (Kline, 2016).

Tablo 2. Model-veri uyum istatistikleri özeti

\begin{tabular}{lccccccl}
\hline Model & \multicolumn{1}{c}{$\chi^{2}$} & $\mathrm{sd}$ & $\mathrm{p}$ & CFI & SRMR & RMSEA & $\begin{array}{l}\text { RMSEA } \\
\% 90 \mathrm{G} . \mathrm{A} .\end{array}$ \\
\hline Ölçme Modeli 1 & 713.360 & 47 & $<.0001$ & .912 & .067 & .164 & $(.154, .175)$ \\
Ölçme Modeli 2 & 222.514 & 47 & $<.0001$ & .977 & .042 & .084 & $(.073, .096)$ \\
Yapısal Regresyon Modeli & 297.047 & 101 & $<.0001$ & .971 & .044 & .061 & $(.053, .069)$ \\
\hline
\end{tabular}

Not: sd, Serbestlik Derecesi, G. A., Güven Aralığı.

Bu çalışmada üç model değerlendirilmiştir. Ölçme Modeli 1, Aktürk, Çelik, Şahin ve Deniz (2014) tarafından oluşturulan ölçme modelidir. Bu modelde iletişimi başlatma boyutu için gösterge değişkenler M1, M2, M3, M4 ve M9'dur. İletişimi sürdürme boyutu için gösterge değişkenler ise M5, M6, M7 ve M8' dir. Son olarak Bilgi arama boyutu için gösterge değişkenler M10, M11 ve M12'dir. Bu modelde dört gösterge değişkeni çifti arasındaki hata varyansı serbestçe hesaplanmıştır ancak neden bu çiftlerin seçildiği gerekçelendirilmemiştir. Bu çiftler; 
M8-M7, M8-M6, M8-M5 ve M3-M1'dir. Bu çalışmada yer alan Ölçme Modeli 1'de serbestçe hesaplanan gösterge değişkenler arası hata varyansları 0 ' da sabitlenmiştir. Tablo 2 ' de yer alan model-veri uyum istatistikleri ve bir önceki paragrafta ele alınan ölçütler göz önüne alındığında Ölçme Modeli 1'in veri uyumunun kötü olduğu söylenilebilir.

Ölçme Modeli 2, Ölçme Modeli 1'den sadece serbestçe hesaplanan hata varyansları anlamında farklılık göstermektedir. FBSÖ sorularına bakıldığında M1 ve M5 sorularının, M2 ve M6 sorularının, M3 ve M7 sorularının ve M4 ve M8 sorularının aynı olduğu görülmektedir. Katılımclar M1, M2, M3 ve M4 sorularını cevaplandırırken yakından tanımadıkları birisini göz önüne almaları, M5, M6, M7 ve M8 sorularını cevaplandırırken ise yakından tanıdıkları birisini göz önüne almaları istenmektedir. Her ne kadar katılımclar farklı yakınlıktaki insanları göz önüne alarak bu soruları cevaplandırsa da soruların kelimesi kelimesine aynı olması bu gösterge değişkenleri arasındaki ortaklığın, ölçülen özelliğin ötesinde olmasını akıllara getirmektedir. Bu nedenle M1-M5, M2-M6, M3-M7 ve M4-M8 gösterge değişkenleri çiftlerinin hata varyanslarının serbestçe hesaplanmasına izin verilerek Ölçme Modeli 2 oluşturulmuştur. Tablo 2' de yer alan Ölçme Modeli 2'ye ait uyum istatistikleri incelendiğinde model-veri uyumunun kabul edilebilir seviyede olduğu söylenilebilir. Her ne kadar tam uyum sağlanmamış olsa da $(p<.001)$.977'lik CFI ve .042'lik SRMR değeri beraber ele alındığında model-veri uyumunun kabul edilebilir seviyede olduğunu söylenilebilir. Son olarak .084'lük RMSEA değeri ve RMSEA için \%90 güven aralı̆̆ının (.073, .096) olması yakın olmayan uyum hipotezini sağlamaktadır. Ölçme Modeli 2'ye ait faktör yükleri ve boyutlar arası ilişkileri özetleyen standartlaştırılmış çözüm sonuçları Şekil 1'de gösterilmiştir.

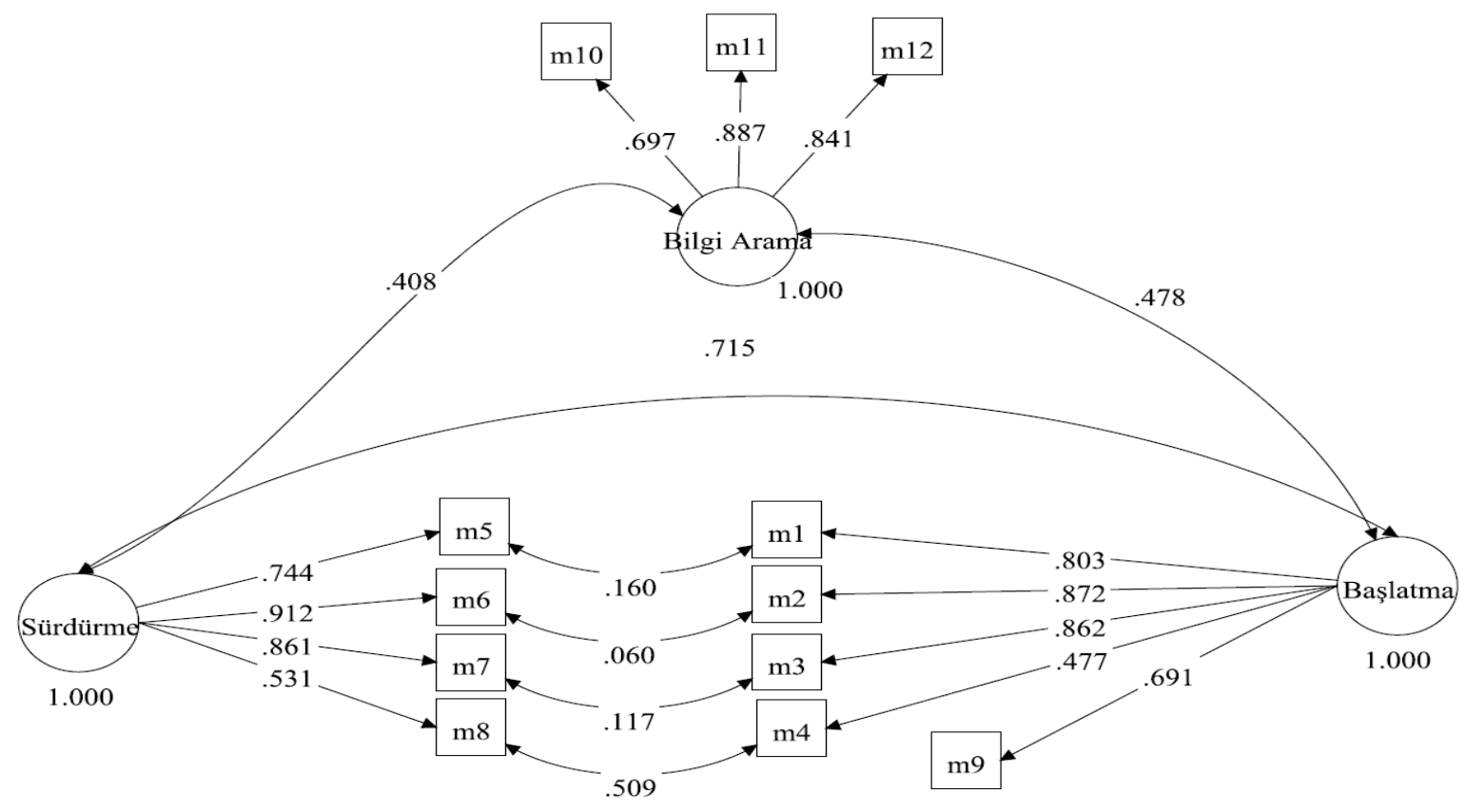

Şekil 1. Ölçme Modeli 2'ye ait doğrulayıcı faktör analizi standartlaştırılmış çözüm sonuçları. 
Şekil 1'e göre boyut puanlarının ortalamalarının 0, standart sapmalarının 1 olduğu standartlaştırma yapılmıştır. Oklarla gösterilen bütün ilişkiler $\alpha=.05$ düzeyinde istatistiksel olarak anlamlıdır. Ayrıca, tün gösterge değişkenlerin ilgili boyutlarla yüksek derecede ilişkili olduğu (faktör yükleri .477 ile .912 arasında değişmektedir) gözlemlenmiştir. Son olarak nedenle M1-M5, M2-M6, M3-M7 ve M4-M8 gösterge değişkenleri çiftlerinin hata varyanslarının serbestçe hesaplanması sonucunda elde edilen varyans istatistiklerinin .060 ile .509 arasında değişmesi ve bunların $\alpha=.05$ seviyesinde istatistiksel olarak anlamlı olması, söz konusu varyansları serbestçe hesaplama kararını doğrulamıştır.

Yapısal Regresyon Modeli, Ölçme Modeli 2 üzerine oluşturulmuştur. Ölçme Modeli 2'ye ek olarak cinsiyet ve bölüm dışsal değişkenleri, FBSÖ'nün her bir boyut puanını yordamaktadır. Cinsiyet için kadın, bölüm içinse BÖTE referans kategorisi seçilmiş, karşılaştırmalar öncelikli olarak referans kategorisine kıyasla gerçekleştirilmiştir. Tablo 2' de yer alan Yapısal Regresyon Modeline ait uyum istatistikleri incelendiğinde model-veri uyumunun kabul edilebilir seviyede olduğu söylenilebilir. Her ne kadar tam uyum koşulu sağlanmamış olsa da $(p<.001)$ .971'lik CFI ve .044'lik SRMR değeri beraber ele alındığında model-veri uyumunun kabul edilebilir seviyede olduğunu gösterir. .061'lik RMSEA değeri iyi uyuma işaret etmektedir. Son olarak RMSEA için \%90 güven aralı̆̆ının (.053, .069) olması yakın olmayan uyum hipotezini sağlamaktadır.

\section{Bulgular}

$\mathrm{Bu}$ bölümde öncelikli olarak birinci araştırma sorusunun cevabına ilişkin ANOVA, $\mathrm{t}$ testi ve etki büyüklügü hesaplamalarına, sonrasında ikinci ve üçüncü araştırma sorularının cevabına ilişkin yapısal regresyon modeli bulgularına yer verilmiştir.

Tablo 3. Ölçeklendirilmiş FBSÖ boyut seviyelerinin betimsel istatistikleri ( $N=525)$

\begin{tabular}{lll}
\hline & Ortalama & Standart Sapma \\
\hline İletişimi Başlatma & 38.981 & 25.668 \\
İletişimi Sürdürme & 54.870 & 28.617 \\
Bilgi Arama & 60.743 & 34.855 \\
\hline
\end{tabular}

Ölçeklendirilmiş FBSÖ boyut seviye ortalamalarını karşılaştırmak için gerçekleştirilen bireyler içi ANOVA sonuçlarına göre boyut seviye ortalamaları arasında istatistiksel olarak anlamlı farklılık tespit edilmiştir $(F(2,1048)=128.24, p<.001)$. Anlamlı farklılığın kaynağını belirlemek için ikili karşılaştırmalar gerçekleştirilmiştir. Ölçeklendirilmiş iletişimi başlatma boyutu seviye ortalaması, ölçeklendirilmiş iletişimi sürdürme boyut seviye ortalamasından 15.888 puan daha azdır. Bu farklılık $\alpha=.0133$ seviyesinde istatistiksel olarak anlamlıdır ( $t$ (1048) =11.301, p<.001). Bu farklılık için hesaplanan Cohen's D etki büyüklüğü istatistiği-.682'dir. Benzer şekilde ölçeklendirilmiş iletişimi başlatma boyutu seviye ortalaması, ölçeklendirilmiş bilgi arama boyut seviye ortalamasından 21.762 puan daha azdır. Bu farklılık $\alpha=.0133$ seviyesinde istatistiksel olarak anlamlıdır $(t$ (1048) $=-15.478, p<.001)$. Bu farklılık için 
hesaplanan Cohen's D etki büyüklügü istatistiği-.624'dür. Son olarak ölçeklendirilmiş iletişimi sürdürme boyutu seviye ortalaması, ölçeklendirilmiş bilgi arama boyut seviye ortalamasından 5.873 puan daha azdır. Bu farklılık $\alpha=.0133$ seviyesinde istatistiksel olarak anlamlıdır $(t(1048)=-4.177, p<.001)$. Bu farklılık için hesaplanan Cohen's D etki büyüklüğü istatistiği-. $160^{\prime} \mathrm{d} ı r$.

Tablo 4. Yapısal regresyon modelinin yapısal bileşeni kestirimleri.

\begin{tabular}{|c|c|c|c|c|}
\hline Parametre & Kestirim & Standart Hata & $\mathrm{t}$ & $\mathrm{p}$ \\
\hline \multicolumn{5}{|l|}{ İletişimi Başlatma } \\
\hline Erkek & 0.734 & 0.104 & 7.070 & $<.001$ \\
\hline Sınıf Öğretmenliği & -0.246 & 0.194 & -1.272 & .203 \\
\hline Türkçe Öğretmenliği & -0.171 & 0.212 & -0.806 & .420 \\
\hline İlköğretim Matematik Öğretmenliği & -0.094 & 0.198 & -0.473 & .636 \\
\hline Sosyal Bilgiler Öğretmenliği & -0.170 & 0.169 & -1.006 & .314 \\
\hline Fen Bilgisi Öğretmenliği & -0.109 & 0.200 & -0.545 & .586 \\
\hline \multicolumn{5}{|l|}{ İletişimi Sürdürme } \\
\hline Erkek & 0.522 & 0.106 & 4.917 & $<.001$ \\
\hline Sınıf Öğretmenliği & -0.100 & 0.190 & -0.526 & .599 \\
\hline Türkçe Öğretmenliği & -0.033 & 0.202 & -0.166 & .868 \\
\hline İlköğretim Matematik Öğretmenliği & -0.085 & 0.206 & -0.414 & .679 \\
\hline Sosyal Bilgiler Öğretmenliği & 0.009 & 0.166 & 0.056 & .955 \\
\hline Fen Bilgisi Öğretmenliği & -0.086 & 0.193 & -0.448 & .654 \\
\hline \multicolumn{5}{|l|}{ Bilgi Arama } \\
\hline Erkek & 0.043 & 0.101 & 0.426 & .670 \\
\hline Sınıf Öğretmenliği & -0.046 & 0.186 & -0.249 & .803 \\
\hline Türkçe Öğretmenliği & 0.033 & 0.172 & 0.191 & .849 \\
\hline İlköğretim Matematik Öğretmenliği & -0.090 & 0.204 & -0.440 & .660 \\
\hline Sosyal Bilgiler Öğretmenliği & 0.100 & 0.156 & 0.643 & .520 \\
\hline Fen Bilgisi Öğretmenliği & 0.058 & 0.181 & 0.320 & .749 \\
\hline İletişimi Başlatma İletişimi Sürdürme & 0.687 & 0.034 & 20.352 & $<.001$ \\
\hline İletişimi Başlatma Uilgi Arama & 0.508 & 0.046 & 11.041 & $<.001$ \\
\hline İletişimi Sürdürme $\circlearrowleft$ Bilgi Arama & 0.414 & 0.051 & 8.170 & $<.001$ \\
\hline
\end{tabular}

Not: Cinsiyet için referans kategorisi kadın, bölüm içinse BÖTE referans kategorisi seçilmiştir.

Tablo 4'de sunulan sonuçlara göre cinsiyet değişkenini ele aldığımızda diğer boyut seviyeleri ve bölümleri aynı olan erkek öğretmen adaylarının iletişimi başlatma boyut seviye ortalamaları kadın öğretmen adaylarının iletişimi başlatma boyut seviye ortalamalarından 0.734 standart sapma daha fazladır. Bu farklılık $\alpha=.05$ seviyesinde istatistiksel olarak anlamlıdır ( $p<.001)$. Ayrıca yine diğer boyut seviyeleri ve bölümleri aynı olan erkek öğretmen adaylarının iletişimi sürdürme boyut puanı ortalamaları kadın öğretmen adaylarının iletişimi sürdürme boyut puanı ortalamalarından 0.522 standart sapma daha fazladır. Bu farklılık $\alpha=.05$ seviyesinde istatistiksel olarak anlamlıdır $(p<.001)$. Ancak bilgi arama boyut seviye ortalamalarında erkek ve kadın öğretmen adayları arasında anlamlı bir farklılık tespit edilememiştir $\mathrm{p}=.670$ ). 
Tablo 4'de sunulan sonuçlara göre FBSÖ'nün üç boyut seviye ortalamaları bölüm değişkenine göre istatistiksel olarak anlamlı bir farklılık göstermemektedir.

Tablo 4' de sunulan sonuçlara göre FBSÖ'nün boyut seviyelerinin kendi aralarındaki ilişkileri incelendiğinde tamamının pozitif yönde ve istatistiksel olarak anlamlı olduğu söylenilebilir. Diğer özellikler kontrol edilerek, en güçlü ilişki $0.687^{\prime}$ lik kovaryans ile iletişimi başlatma ve iletişimi sürdürme boyut seviyeleri arasındadır ( $p<.001)$. Bunu, 0.508'lik kovaryans ile iletişimi başlatma ve bilgi arama boyut seviyeleri arasındaki ilişki takip etmektedir ( $p<.001)$. En zayıf ilişki ise $0.414^{\prime}$ lük kovaryans ile iletişimi sürdürme ve bilgi arama boyut seviyeleri arasındadır $(p<.001)$.

\section{Tartışma ve Sonuç}

Öğretmen adaylarının Facebook'a bağlanma gerekçelerini belirlemeyi amaçlayan bu araştırmada, ilk önce öğretmen adaylarının Facebook'a bağlanma gerekçe seviyeleri, sonra öğretmen adaylarının Facebook'a bağlanma gerekçe seviyelerinin cinsiyet ve bölüm dışsal değişkenlere göre anlamlı bir farklılık gösterip göstermediği ve son olarak da öğretmen adaylarının Facebook'a bağlanma gerekçeleri arasındaki ilişkinin yönü ve miktarı sunulmuştur.

Çalışmada öğretmen adayların Facebook'a iletişimi başlatma amaçlı bağlanmalarının, iletişimi sürdürme amaçlı bağlanmalarına göre daha az olduğu belirtilmiştir. Bu farkın orta etki derecesinde olduğu saptanmıştır. Buna göre öğretmen adayları Facebook'u yeni arkadaşlar ile tanışmak yerine var olan yakın arkadaşları ile iletişim ve ilişkilerini güçlendirmek gerekçesiyle kullandıkları görülmüştür. Bu çalışma bulgularıyla paralel olarak Günindi Ersöz (2016), öğrencilerin Facebook kullanma nedenlerinden birisinin arkadaşlarıyla ilişkide kalmak olduğunu belirtmiştir. Solmaz, Tekin, Herzem ve Demir (2013) çalışmalarında benzer şekilde katılımcıların sosyal ağları yeni arkadaşlarla tanışmak yerine arkadaşlarıyla iletişimde olmak için kullandıkları belirtilmiştir. Buna karışın Aktürk, Emlek ve Çelik (2017) araştırmalarında arkadaşları ile aynı yerde kalan öğrencilerin Facebook'u daha çok yeni arkadaşlar ile tanışma amaçlı kullandıklarını bulmuşlardır.

Çalışmada, öğretmen adaylarının Facebook'a iletişimi başlatma amaçlı bağlanmalarının, bilgi arama amaçlı bağlanmalarına göre daha az olduğu belirtilmiştir. Bu farklılı̆̆ın orta etki derecesine sahip olduğu saptanmıştır. Dolasıyla öğretmen adayları, Facebook'u yeni arkadaşlar ile tanışmak yerine sınıf arkadaşlarını ve yakındaki bireyleri araştırmak ve onların hakkında daha fazla bilgi edinmek için kullandıkları belirtilmiştir. Bu bulgu Aktürk, Emlek ve Çelik'in (2017) büyük ve orta şehirlerden gelen öğrencilerin Facebook'u daha çok bireyler hakkında bilgi arama amacıyla kullandıkları bulgusu ile benzerlik göstermektedir. Aynı şekilde Kobak ve Biçer (2008) öğrenciler Facebook'u arkadaş bulmak sitesinden daha çok arkadaşlarını arama sitesi olarak algıladıklarını ifade etmiştir. 
Çalışmada öğretmen adayların Facebook'a iletişimi sürdürme amaçlı bağlanmalarının, bilgi arama amaçlı bağlanmalarına göre daha az olduğu bulgulanmıştır. Bu farkın küçük etki derecesinde olduğu saptanmıştır. Bu duruma göre öğretmen adayları Facebook'u var olan yakın arkadaşları ile iletişim ve ilişkilerini güçlendirmek yerine sınıf arkadaşlarını ve yakındaki bireyleri araştırmak ve onların hakkında daha fazla bilgi edinmek için kullandıkları görülmüştür. Serdar, Harmandar Demirel ve Demirel'in (2018) öğretmen adaylarının Facebook'ta davranışlarının temelinde diğer bireylerin ne yaptığının merak edilmesi olduğunu ifade etmişlerdir. Günindi Ersöz'ün (2016) yaptığı çalışmaya göre öğrenciler, arkadaşlarının ne yaptıkları hakkında bilgi edinmenin, onlar ile iletişim ve ilişki sürdürmenin yolu olarak algıladıkları belirtilmiştir.

Çalışmada erkek öğretmen adayların, kadın öğretmen adaylarına nazaran Facebook'a yeni bireylerle tanışmak ve var olan yakın arkadaşları ile iletişim ve ilişkilerini güçlendirmek için daha çok bağlandıkları söylenebilir. Bu bulgulara paralel olarak Aktürk, Emlek ve Çelik (2017) çalışmalarında da erkek öğrencilerin kadın öğrenciler göre Facebook'u yeni insanlarla tanışmak ve arkadaşlarıyla ilişikleri sürdürmek için daha çok kullandıklarını söylemişlerdir. Filiz, Erol, Dönmez ve Kurt (2014) çalışlarında erkek öğrencilerin kadın öğrencilere göre sosyal ağları tanıma amacıyla kullanmayı daha çok tercih ettiklerini belirtmişleridir. Benzer şekilde Sheldon (2008) çalışmasında erkek öğrenciler Facebook'u yeni arkadaşları tanışmak için kullanırken kadın öğrencilerin mevcut arkadaşlıkların devam ettirmek için kullandıklarını ifade etmiştir. Bu bulgudan farklı olarak Diker ve Uçar (2016) tarafından yapılan çalışmada sosyal ağlarda iletişimi başlatma ve kurma amacında hem erkek hem de kadın öğrenciler arasında farkın olmadığı, ancak kadın öğrencilerin erkek öğrenciler göre sosyal ağları daha çok iletişimi sürdürmek amaçlı kullandığı belirtilmiştir. Ayrıca hem erkek hem de kadın öğretmen adaylarının benzer seviyelerde Bilgi Arama amacıyla Facebook'a bağlandıkları bulgulanmıştır. Aktürk, Emlek ve Çelik (2017) yaptığı çalışmada erkek ve kadın öğrencilerin Facebook'a bilgi arama için aynı seviyede bağlandıklarını belirtmiştir.

Ayrıca, çalışmada ele alınan altı bölümde kayıtlı öğretmen adayların Facebook'a bağlanma stratejileri benzerlik göstermektedir. Serdar, Harmandar Demirel ve Demirel (2018) çalışmalarında üniversite öğrencilerin Facebook kullanımları bölümlerine göre anlamlı bir şekilde değişmediğini tespit etmişlerdir. Aynı şekilde Ramazanoğlu ve Çetin (2019) çalışmalarında öğretmen adaylarının sosyal ağ sitelerinin kullanım amaçları (sosyal etkileşimiletişim amaçlı kullanım, tanıma ve tanınma amaçlı kullanım ve eğitim amaçlı) bölümlerine göre aynı düzeyde olduğunu bulmuşlardır. Bu sonuçlar, mevcut çalışma ile benzerlik göstermektedir. Bu bulgudan farklı olarak Çam (2012) yaptığı çalışmasında öğretmen adaylarının Facebook kullanım amaçlarının öğrenim gördüklerin bölümlere göre değiştiğini belirlemiştir.

Son olarak çalışmada öğretmen adayları, Facebook'a bağlanma gerekçeleri; iletişimi başlatma, iletişimi sürdürme ve bilgi arama boyutları arasındaki ilişkinin pozitif yönde olduğu 
bulunmuştur. Öğretmen adayların Facebook'a iletişimi başlatma amaçla bağlanırken, yüksek derecede iletişimi sürdürme amaçlı da bağlandığı ve orta derecede bilgi arama amaçlı bağlandığı görülmüştür. Ayrıca öğretmen adaylarının Facebook'a iletişimi sürdürme amaçla bağlanırken, orta derece de bilgi arama amaçlı bağlandığı belirlenmiştir. Yapılan alan yazın taraması dâhilinde, Facebok'a bağlanma gerekçelerinin birbirleri ile ilişkisini karşılaştıran bir çalışma yer almamaktadır.

Öğretmen adaylarının Facebook'a bağlanma gerekçelerinin belirlenmesini amaçlayan bu çalışmada elde edilen bulgular ışı̆̆ında uygulamacılara ve araştırmacılara yönelik çeşitli öneriler getirilmiştir. Uygulamacılara yönelik olarak; özellikle Eğitim Fakültelerinde Facebook'u eğitsel amaçlı kullanmak isteyen öğretim elemanları, Facebook üzerinden etkileşimi sadece aynı sınıftaki öğrenciler ile sınırlı tutmalıdır. Bu durumun gerekçesi, insanların tanımadıkları birisiyle iletişim başlatma amacıyla Facebook kullanmaktan çekinmesidir. Ayrıca Facebook'a en çok bilgi arama gerekçesiyle bağlanıldığ bazı bilgileri Facebook üzerinden bulmasını sağlayacak eğitsel ortamlar tasarlamak faydalı olacaktır. Son olarak Facebook'a bağlanma gerekçelerinde bölüme göre bir farklılık tespit edilemediği için tasarlanan eğitsel ortamların Facebook'a bağlanma içeren kısımlarında bölüme göre bir değişiklik yapılmaması gerektiği önerilmektedir.

Araştırmacılara yönelik öneriler arasında ise bu çalışma ile elde edilen sonuçlarının geçerliğini artırmak için farklı bölgelerden üniversitelerde ve farklı bölümlerde bu çalışmanın tekrarlanması önerisi başı çekmektedir. Özellikle örnekleme yönteminin sınırlılıklarından kaynaklı olarak, bu çalışmanın sonuçlarını evrene genellemek olanaksızdır. Ayrıca öğrencilerin Facebook'a bağlanma gerekçelerinin sosyal sermayeyle, ders başarısıyla ve akademik özyeterlik ile ilişkisi incelenmeye değer görülmektedir. Son olarak, başka sosyal ağ siteleri ile tasarlanacak eğitsel ortamlara ışık tutması nedeniyle benzer çalışmalar başka sosyal ağ sitelerini merkeze alarak yürütülmelidir.

\section{Kaynkaça}

Aktürk, A. O., Çelik, İ., Şahin, İ., \& Deniz, M. E. (2014). Facebook bağlanma stratejileri ölçeğinin Türkçe uyarlama çalışması. Ilköğretim Online, 13(1),319-333.

Aktürk, A. O., Emlek, B., \& Çelik, İ. (2017). Üniversite öğrencilerinin facebook bağlanma stratejilerinin ve yaşam doyumlarının incelenmesi. Mersin Üniversitesi Ĕ̆itim Fakültesi Dergisi,13(2): 512-530. DOI: http://dx.doi.org/10.17860/mersinefd.336739

Bandalos, D.L. (2014) Relative Performance of Categorical Diagonally Weighted Least Squares and Robust Maximum Likelihood Estimation, Structural Equation Modeling: A Multidisciplinary Journal, 21(1), 102-116, DOI: 10.1080/10705511.2014.859510

Bolat, Y., (2018). A Research on the use of Social Media Networks by Teacher Candidates. Journal of curriculum and Teaching, 7, 147-157. 
Cohen J. (1988). Statistical power analysis for the behavioral sciences. New York, NY: Routledge Academic.

Çam, E. (2012). Öğretmen adaylarının eğitsel ve genel amaçlı facebook kullanımları ve facebook bağımlılikları (SAÜ Eğitim Fakültesi Örneği). Yayımlanmamış yüksek lisans tezi, Sakarya Üniversitesi, Sakarya.

Diker, Z., \& Uçar, M. (2016). Üniversite öğrencilerinin sosyal ağları kullanım amaçlarına yönelik bir araştırma: Safranbolu meslek yüksekokulu örneği. Eğitim ve Öğretim Araştırmaları Dergisi.5 (1) Makale No: 38

Ellison, N.B., Steinfield, C., \& Lampe, C. (2011). Connection strategies: social capital implications of Facebook-enabled ommunication practices. New Media \& Society.13(6), 873-892.

Feller, W. (1971). An introduction to probability theory and its applications, Vol. 2, 3rd ed. New York: Wiley.

Filiz, O., Erol, O., Dönmez, F. İ., \& Kurt, A. A. (2014). Böte bölümü öğrencilerinin sosyal ağ siteleri kullanım amaçları ile internet bağımlılıkları arasındaki ilişkinin incelenmesi. Journal of Instructional Technologies \& Teacher Education,3 (2), 17-28.

Flora, D. B., \& Curran, P. J. (2004). An Empirical Evaluation of Alternative Methods of Estimation for Confirmatory Factor Analysis With Ordinal Data. Psychological Methods, 9(4), 466-491. https://doi.org/10.1037/1082-989X.9.4.466

Fraenkel, J. R., Wallen, N. E., \& Hyun, H. H. (2012). How to design and evaluate research in education (Eight Edition). New York: McGraw-Hill.

Gonzales, L., \& Vodicka, D. (2010). Top 10 Internet resources for educators. Leadership,39(3), 8-37.

Günindi Ersöz, A. (2016). Üniversite öğrencilerinin facebook kullanma alışkanlıkları: sosyoloji bölümü öğrencileri örneği. Sosyoloji Konferansları No: 53 (2016-1) / 303-326.

Hargittai, E. \& Hsieh, Y.-L.P. (2010). Predictors and consequences of differentiated practices on Social Network Sites. Information, Communication \& Society, 13(4), 515-536.

Hew, K. F. (2011): Students' and teachers' use of Facebook. Computers in Human Behavior, 27 (2), 662676.

Hu, L. \& Bentler, P. (1999). Cutoff criteria for fit indices in covariance structure analysis: conventional criteria versus new alternatives. Structural Equation Modeling, 6, 1-55.

Kaptan, S. (1998). Bilimsel arastirma ve istatistik teknikleri. Ankara: Tekisik Web Ofset Tesisleri.

Karasar, N. (2015). Bilimsel araştırma yöntemleri. Ankara: Nobel Yayın Dağıtım.

Kim, W., Jeong, O. R., \& Lee, S. W. (2010). On social web sites. Information Systems, 35(2), 215-236.

Kline, R. B. (2016). Methodology in the social sciences. Principles and practice of structural equation modeling (4th ed.). Guilford Press.

Kobak, K., \& Biçer, S. (2008). Facebook sosyal paylaşım sitesinin kullanım nedenleri. 8 th International Educational Technology Conference. Eskişehir: Anadolu University, May 06-09, 2008, 567-571. 
Korkmaz, İ. (2012). Facebook ve mahremiyet: Görmek ve gözetlenmek. Yalova Sosyal Bilimler Dergisi, 5, $107-122$.

Kuznetsova A., Brockhoff P.B., \& Christensen R. H. B. (2017). lmerTest package: tests in linear mixed effects models. Journal of Statistical Software, 8 (13), 1-26. doi: 10.18637/jss.v082.i13 (URL: https://doi.org/10.18637/jss.v082.i13).

Li, C. H. (2016). Confirmatory factor analysis with ordinal data: Comparing robust maximum likelihood and diagonally weighted least squares. Behavior Research Methods, 48(3), 936-949.

Lua, A. (2019, Ocak 24). 21 top social media sites to consider for your brand [Blog Post]. Erişim adresi https://buffer.com/library/social-media-sites

Miller, R. G. (1981). Simultaneous statistical inference, 2nd ed. New York: Springer-Verlag.

Muthén, L. K., \& Muthén, B. O. (2012). Mplus user's guide (7 edn). Los Angeles, CA: Muthén \& Muthén.

Pempek, T. A., Yermolayeva, Y. A., \& Calvert, S. L. (2009). College students' social networking experiences on Facebook. Journal of Applied Developmental Psychology, 30(3), 227-238.

R Core Team (2019). R: A language and environment for statistical computing. R Foundation for Statistical Computing, Vienna, Austria. URL https://www.R-project.org/.

Ramazanoğlu, M., \& Çetin, A. (2019). Öğretmen adaylarımın sosyal ă̆ siteleri kullanım amaçlarımın farklı değişkenlere göre incelenmesi. Uluslararası Fen, Matematik, Girişimcilik ve Teknoloji Eğitimi Konferansi. No: 263

Sass, D.A., Schmitt, T.A., \& Marsh, H.W. (2014) Evaluating Model Fit With Ordered Categorical Data Within a Measurement Invariance Framework: A Comparison of Estimators. Structural Equation Modeling, 21 (2), 167-180. DOI: 10.1080/10705511.2014.882658

Satterthwaite, F. (1946). An Approximate Distribution of Estimates of Variance Components. Biometrics Bulletin, 2(6), 110-114. DOI:10.2307/3002019

Serdar, E., Harmandar Demirel, D., \& Demirel, M. (2018). Üniversite Öğrencilerinin Facebook Kullanımı ile Yalnızlık Düzeylerinin İncelenmesi. Uluslararası Sosyal Araştırmalar Dergisi. 11(60), ss.14021409.

Sheldon, P. (2008). Student favourite: Facebook and motives for its use. Southwestern Mass Communication Journal, 23(2), 39-53.

Solmaz, B., Tekin, G., Herzem, Z., \& Demir, M. (2013). İnternet ve sosyal medya kullanımı üzerine bir uygulama. Selçuk İletişim, 7 (4), 23-32.

Wang, S. S., Moon, S., Kwon, K. H., Evans, C. A. \& Stefanone, M. A. (2010). Face off: Implications of visual cues on initiating friendship on facebook. Computers in Human Behaviour, 26(2), 226-234. 